LITERATURA AFRICANA 


\section{Entre o satírico e o lírico: o vôo poético de Mia Couto}

Jorge Valentim

Universidade Federal do Rio de Janeiro / Universidade Gama Filho

O olho do poeta-narrador vê o deserto. A memória traz a imagem de civilizações derruídas. A consciência se pergunta sobre o sentido da visão e das lembranças; e responde pela certeza de que a sorte do homem é precária. (...) Resta ao coração sentir a angústia do aniquilamento que a fumaça do monte não cessa de anunciar. Pensar é, também (...), aprender a morrer.

ALFREDO BOSI. O ser e o tempo da poesia.

\section{1- O satírico e o lírico no discurso poético}

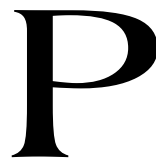

artindo da idéia apontada na epígrafe de Alfredo Bosi, o ato de criação poética está diretamente ligado ao de nomeação às coisas e aos seres, porquanto ao poeta é dado o poder de tirar do nada, de doar sentidos, enfim, de formar e (re)criar todo um universo, através de seu discurso. Ou seja, do Caos ao Cosmos, ele é o agente, o proclamador do fiat lux, o instaurador de um verbum mito-poético.

Para o ensaísta brasileiro ${ }^{1}$, o discurso poético, desde a Antigüidade à Modernidade, passa por um processo transitório, que vai do poder cativante da poesia ao poder cativeiro da imagem. Na tentativa de driblar a imposição das imagens capitalistas, surgidas no auge dos tempos modernos, o poeta viu-se compelido a transformar seu canto, sua voz, sua lira criadora, numa espécie de grito, tal como o propuseram certas escolas

${ }^{1}$ BOSI, 2000, p. 222. 
artísticas de Vanguarda, como o Expressionismo de um Münch (O Grito) ou de um Schöenberg (Noite Transfigurada e O Pierrot Lunático). Logo, diante de uma Modernidade (e, para alguns, de uma Pós-Modernidade ${ }^{2}$ ) marcada pelo desgaste e pela erosão das utopias, a palavra poética finca sua bandeira no espaço ruído das distopias, como forma inequívoca de resistência e sobrevivência.

Sob o signo desta inevitável resistência, o discurso poético desenvolveria, pelo menos, duas faces: uma lírica e outra satírica. A primeira se manifestaria ora através da poesia mítica, tentativa de voltar ao tempo original e recuperar o sentido comunitário perdido ou esquecido, numa experiência direta do sujeito lírico com a tradição milenar, ora através do lirismo de confissão, proposta de uma prosa fortemente carregada de melodia dos afetos, cujo exemplo tutelar estaria nos escritos ardentes de Rousseau. Já a segunda, encontraria na paródia, na sátira, o espaço adequado para destilar uma crítica direta ou velada à desordem estabelecida pela poder imposto.

Ora, há-de se observar que, ao reconhecer-se como palavra de resistência, o discurso poético acaba voltando-se para dentro de si próprio, na medida em que eleva a sua estrutura a um estatuto de importância fundamental, pois, é através dela, que ele próprio atinge a condição de discurso questionador de um código imposto. Entramos, assim, no salutar e movediço terreno da metalinguagem. Mas a metalinguagem não deve apenas ser entendida no sentido burocrático e acadêmico da palavra, como o "da produção pela produção, do papel que gera papel, da letra que gera letra, da rapidez, da eficácia pela eficácia”’. Antes, deve ser compreendida como aquele "momento vivo da consciência que me

${ }^{2} \mathrm{O}$ termo é por demais discutido. Na crítica atual, encontramos aqueles que o defendem categoricamente, como é o caso de Linda Hutcheon, e outros que o questionam, como o faz Terry Eagleton. A proposta, aqui, não é discutir a terminologia, nem tão pouco procurar vestígios existentes ou não na prosa de Mia Couto. Tanto num caso quanto no outro, o importante é sublinhar a produção do autor moçambicano na rota da fragilidade das fronteiras entre os gêneros, com uma linguagem romanesca em constante diálogo com o discurso poético, numa literatura que se quer pertencente a uma Modernidade ou Pós-Modernidade, como o quiserem optar.

${ }^{3}$ BOSI, 2000, p. 172. 
aponta os resíduos mortos de toda retórica, antiga ou moderna; e com a paródia, ou com a pura e irônica citação, me alerta para que eu não caia na ratoeira da frase feita ou do trocadilho compulsivo" ${ }^{4}$. Desta forma, os dois lados do discurso poético - o lírico e o satírico - estariam diretamente envolvidos com o processo criador de nomeação de seres, sem qualquer ordem ou grau de importância. Cada um deles constituiria uma maneira distinta de o poeta verbalizar o seu fiat lux.

Assim entendida, a metalinguagem sintoniza com a lucidez do pensar poético que "dá à palavra um novo, intenso e puro modo de enfrentar-se com objetos" "É o "catar feijão"6 de João Cabral de Melo Neto; é o penetrar "surdamente no reino das palavras" à procura da poesia, de Drummond; é o "ruminante delírio das palavras" de Eduardo White; ou, ainda, é o reencontro com "a palavra sem endereço", de Mia Couto, que confirmam o recurso metalingüístico como importante instrumento no resgate salutar da resistência e da sobrevivência do discurso poético.

A partir dos pressupostos teóricos de Alfredo Bosi, propomos como roteiro de leitura do romance de Mia Couto, O último vôo do flamingo (2000), um passeio pelos dois espaços poéticos de sua prosa - o satírico e o lírico -, observando as suas manifestações textuais e dialogando, sempre que necessário, com outros de sua autoria, tanto os ficcionais, quanto os poéticos. Do contar ao cantar, do falar ao escrever, as vozes romanescas se entretecem e constroem uma narrativa sob o signo de Orfeu. Vôos, sonhos, sons e flamingos são convocados poeticamente para anunciar um novo nascer do sol.

\section{2 - As faces poéticas da prosa de Mia Couto}

Escritor internacionalmente reconhecido, detentor de importantes prêmios literários, Mia Couto é já um nome que dispensa quaisquer

\footnotetext{
${ }^{4}$ BOSI, 2000, p. 172.

5 BOSI, 2000, p. 173.

${ }^{6}$ MELO NETO, 1997, p. 16.

7 ANDRADE, 1983, p. 160.

${ }^{8}$ WHITE, 1992, p. 17.

${ }_{9}$ COUTO, 1999a, p. 22.
} 
apresentações biográficas. Como ficcionista, desenvolveu-se, sobretudo, nos gêneros do conto, com as obras Vozes Anoitecidas (1987), Estórias Abesonhadas (1994), Contos do nascer da terra (1997) e, posteriormente, do romance, com Terra Sonâmbula (1992), A Varanda do Frangipani (1996), Vinte e Zinco (1999), O último vôo do flamingo (2000), Um rio chamado tempo, uma casa chamada terra (2002), apenas para citar algumas.

Interessante observar que a trajetória deste ficcionista principia com uma e única experiência pela poesia. Com Raiz de Orvalho, Mia Couto estréia em 1983, vindo a republicar a mesma obra em 1999, com acréscimos de novos poemas, revisão de alguns e depuração de outros. Apesar de, no prefácio de sua segunda edição, o autor confessar ser "um poeta cuja prosa é muito distante daquilo que se pode pressentir em Raiz de Orvalbo" ${ }^{10}$, preferimos antes pensar a coexistência do discurso poético no discurso ficcional, posto que, como afirmaria em seguida, sem a escrita de Raiz de Orvalho, ele "nunca experimentaria outras dimensões da palavra"11.

Se foi de Raiz de Orvalho que o escritor partiu "a desvendar outros terrenos"12, como os do conto e os do romance, é certo que o fez sem jamais se desvencilhar das raízes poéticas que gerariam tantos outros ramos e orvalhos narrativos. Logo, tratar da escrita ficcional de Mia Couto implica necessariamente caminhar pelo território das fronteiras dos gêneros, pois, o seu vôo abriga um roteiro que vai da poesia ao romance, do poético ao narrativo, sem deixar brechas ou vácuos, mas apenas espaços a serem percorridos, com aquela certeza de que "todo romance é, nem que seja minimamente, poema, e todo poema é, ao menos num mínimo grau, narrativa"13. É ainda certo pontuar, como o fez Yves Stalloni, que "ocasionalmente ou de forma contínua, (...) uma obra literária em prosa dê mostras, por seu valor musical, estilístico ou lexical, de afinidades com o texto poético"14. Estes conceitos levam-nos, portanto, a refletir sobre

\footnotetext{
${ }^{10}$ COUTO, 1999a, p. 7.

${ }^{11}$ COUTO, 1999a, p. 7.

${ }^{12}$ COUTO, 1999a, p. 7.

${ }^{13}$ TADIÉ, 1978, p. 7.

${ }^{14}$ STALLONI, 2000, p. 168.
} 
a prosa de Mia Couto, como uma instância sob o signo de Orfeu, e, portanto, escrita e inscrita sob os signos paródico dionisíaco e mitopoético apolíneo. O próprio autor, em entrevista a Nelson Saúte, declara a fragilidade das linhas divisórias entre os gêneros literários: "(...) nem sequer acredito na fronteira entre poesia e prosa"15. Assim, mais adequado que rotular O Ultimo Vôo do Flamingo, romance publicado em 2000, em gêneros como romance, que o é; ou como prosa poética, que também possui, preferimos arriscá-lo - mas, também, sem nenhuma pretensão definitiva - bem próximo do âmbito de uma narrativa poética porquanto finca sua presença no gênero romanesco, sem abrir mão do discurso tipicamente poético. Acreditamos também que o discurso romanesco dá conta de uma veia satírica e de uma eclosão lírica, tecendo-se, assim, mediante a experiência poética do sujeito narrante. Entre a prosa e o poético, entre o satírico e o lírico, entre a resistência e a permanência, estas seriam aquelas outras asas do seu "vôo de escrever"16. Desta forma, Mia Couto não seria apenas um poeta em tempos de prosa, mas um prosador no eterno tempo do poético, ou, como diria Bosi, no "tempo órfico, revivido, em que o domínio e o cálculo ficam suspensos enquanto dura o encanto"17.

Colocam-se, assim, em evidência, as duas faces da escrita poética do texto ficcional de Mia Couto: de um lado, a carnavalização, a paródia e o irônico, presentes nas situações mais insólitas e surreais, como a explosão, o sumiço e a decepação dos Boinas Azuis, e de outro, a poeticidade e a miticidade do contar, reveladoras da recuperação da história, das fontes míticas originais e de certos personagens que nela transitam e interferem. E, seu texto confirma-se, assim, como aquele "produto de uma semiose que funde, literariamente, lirismo e lucidez na captação do mundo e da existência"18.

Com este narrador-poeta que prefere o olhar deslocado, aquele que vê por outro lado, o leitor inicia a viagem textual com o olhar de trás, porque "é onde melhor se vê e menos se é visto"19. É com esta outra forma

\footnotetext{
15 SAÚTE, 1998, p. 228.

${ }^{16}$ COUTO, 1999b, p. 19.

${ }^{17}$ BOSI, 2000, p. 181.

${ }^{18}$ SECCO, 1998, p. 160.

${ }^{19}$ COUTO, 2000, p. 17.
} 
de ver, de desejar um novo princípio, que o discurso poético alça vôo nas asas do flamingo e anuncia o sol da ficção.

\section{3 - Os jogos poéticos da resistência: a paródia e a ironia}

De acordo com Alfredo Bosi,

(...) na luta contra a ideologia e o estilo vigentes, o satírico e o parodista devem imergir resolutamente na própria cultura. É dela que falam, é a ela que se dirigem. Tal imersão não se faz sem riscos e arrepios: não há nenhum outro gênero que denuncie mais depressa o partido do escritor, as suas antipatias, mas também as suas ambigüidades morais e literárias. ${ }^{20}$

Neste sentido, sublinhar o satírico e o paródico em Mia Couto implica diretamente atentar para um discurso contra-ideológico, no sentido de que o risco do vôo e a vertigem e o arrepio do sonho constituem a arma textual para fugir do enganoso jogo de espelhos do poder, sem deixar de lado as marcas culturais das vozes que emergem da ficção. Estas, a princípio, apesar de bem distintas, convivem pacificamente no texto, porque são transcritas e traduzidas por um narrador / tradutor, cujo ofício já denuncia a intimidade do olhar narrante com a sucessão dos acontecimentos. Além disto, constituem-se como vozes marginais, ao lado das femininas, como a de AnaDeusqueira, trazidas à tona pelo narrador, que, numa busca recuperadora da origem cultural, reúne as lembranças da memória e do corpo como as raízes do narrado:

Fui eu que transcrevi, em português visível, as falas que daqui se seguem. Hoje são vozes que não escuto senão no sangue, como se a sua lembrança me surgisse não da memória, mas do fundo do corpo. É o preço de ter presenciado tais sucedências. Na altura, eu era tradutor ao serviço da administração de Tizangara. Assisti a tudo o que aqui se divulga, ouvi confissões, li depoimentos. Coloquei tudo no papel por mando de minha consciência. Fui acusado de mentir, falsear as provas de assassinato. Me condenaram. Que eu tenha mentido, isso não aceito.

${ }^{20}$ BOSI, 2000, p. 191-192. 
Mas o que se passou só pode ser contado por palavras que ainda não nasceram. ${ }^{21}$

Narrador muito peculiar, este, que conta não pelo que o outro viu, mas pelo seu próprio testemunho, porque presenciou as "sucedências", mesmo que com o olhar por detrás. Prática muito comum na escrita miacoutiana, no romance, encontramos o remoer das memórias e o desenterrar das lembranças, comparados ao escavar de sepulturas. A fala de Nãozinha, a feiticeira, vaticina a tentativa da busca de imagens pretéritas. O narrado ganha corpo, porque é do corpo que também saem suas recordações e se corporificam na narrativa: "Minhas lembranças são custosas de chamar. (...) Ninguém obedece senão em fingimento. Não destine ordem em minha alma. Senão quem vai falar é só o meu corpo"², 81). Densas como o corpo, não sujeitas a uma ordem imposta, as lembranças são fluidas e movediças, porque são resgatadas sob o signo dinâmico da água: "As minhas lembranças são seres morridos, sepultados não em terra mas em água. Remexo nessa água e tudo se avermelha"²3.

Outra postura peculiar do narrador é a transcrição das "sucedências" "em português visível". Relembrar, remexer, transcrever e traduzir constituem o vocabulário do narrador que, na contra-corrente ideológica do poder dominante, recusa a ordem do tempo imposto e propõe uma nova ordem temporal, "pisando memórias, arriscando fantasmas" ${ }^{24}$. Em O Último Vôo do Flamingo, é o mando da consciência e a sua vontade que regem a sucessão dos acontecimentos. O mistério paira sob a busca da verdade, colocando o leitor na margem do narrado e convidando-o a participar de sua viagem, de seu vôo: "Deixo-vos na procura da resposta, ao longo destas páginas" 25 . Mas, esta busca pela resposta, esta recusa em aceitar o fingimento, a mentira, não seria uma das artimanhas deste narrador-sedutor? Em Terra Sonâmbula, encontramos um aviso denunciador semelhante: "Quero pôr os tempos, em sua mansa ordem, conforme esperas e sofrências. Mas as lembranças desobedecem, entre

\footnotetext{
${ }^{21}$ COUTO, 2000, p. 11.

${ }^{22}$ COUTO, 2000, p. 81.

${ }^{23}$ COUTO, 2000, p. 81.

${ }^{24}$ COUTO, 2000, p. 68.

${ }^{25}$ COUTO, 2000, p. 12.
} 
a vontade de serem nada e o gosto de me roubarem do presente. Acendo a estória, me apago a mim"26.

Pois é no desobedecer das lembranças, no obedecer só em fingimento, no acender da estória, no apagar-se a si próprio diante das vozes, outrora anoitecidas e agora, amanhecidas no texto, que a proposta de escrita do romance se situa. Ao expurgá-las, revolve as águas turvas da memória e lança as palavras no papel, como um assassino que "se livra do corpo da vítima" 27 .

A voz do outro é resgatada da margem como confissão ouvida e como depoimento lido, reunindo-se, assim, o oral e o escrito na narrativa romanesca. Colhidas as palavras, costuradas as vozes, o narrador/tradutor/ transcritor declara categoricamente: "Agora, vos conto tudo por ordem de minha única vontade"28. É sob a sua vontade que o contar se transforma num "cantar ao lado de"29, posto que se tece parodicamente como conto/ canto ao lado do discurso oficial. Somadas à sua, as vozes marginais se levantam contra a fala do poder. Neste sentido, o próprio texto romanesco se constitui numa grande paródia, porque reúne depoimentos dos personagens representativos da ordem - como o Administrador Estevão Jonas -, acaba por atuar transgressoramente e também faz ecoar os "cantos" do narrador-poeta e de certos personagens, como elementos desestabilizadores das certezas impostas. Trata-se, portanto, de uma narrativa onde a paródia vem acompanhada da ironia e do satírico, porque, afinal de contas, são eles que desfazem os alicerces instituídos e refazem as novas bases. A palavra de ordem, agora, é a palavra de/em liberdade, é a palavra contada, enfim, é a palavra inventada.

No seu "vôo de escrever", o narrador situa o leitor nos anos iniciais do pós-guerra, contextualizando-o, portanto, no cenário de um Moçambique "fraccionado na perplexidade dos novos tempos, em que a miséria se sustenta do ganho fácil e da despersonalização cultural"30.

Com um olhar crítico diante desta realidade estilhaçada pelos desmandos do pós-guerra, o narrador resgata algumas vozes sufocadas

\footnotetext{
${ }^{26}$ COUTO, 1995, p. 17.

${ }^{27}$ COUTO, 2000, p. 11.

${ }^{28}$ COUTO, 2000, p. 11.

${ }^{29}$ HUTCHEON, 1991, p. 47.

${ }^{30}$ LEITE, 2000, p. 253.
} 
pelo discurso ideológico, expõe alguns acontecimentos sob o signo da comicidade e apresenta caricaturalmente os personagens representantes do poder instituído na cidade imaginária de Tizangara. Neste sentido, a presença da prostituta Ana Deusqueira é sintomática para desvelar o seu teor satírico e paródico.

A guardiã dos encantos e dos desejos dos habitantes de Tizangara, chamada pelas autoridades locais para desvendar um mistério, contrasta com a solenidade requerida pela chegada da comitiva da ONU. A fim de prender a atenção do leitor, o narrador não hesita em apelar ao humor e à ironia dos acontecimentos, revelando desde já a sua postura irreverente e a sua intencionalidade ridicularizadora. O suposto respeito "a jeito de cerimónia militar"31 cai por terra diante de um cabrito atropelado, que, agonizante, atrapalha o momento de solenidade.

A situação se torna mais flagrante e irônica, com a chegada da prostituta Ana Deusqueira. Se, num primeiro momento, a formalidade é quebrada pelo cabrito, em seguida, a pompa e a grandiloqüência dos ministros e representantes da ONU são desestruturadas pela irreverente chegada da mulher:

Já Ana Deusqueira se anunciava, com menos sirene que a delegação, mas com maiores espampanâncias. A mulher exibia demasiado corpo em insuficientes vestes. Os tacões altos se afundavam na areia como os olhos se espetavam nas suas curvaturas. O povo, em volta, olhava como se ela fosse irreal. Até recentemente não existira uma prostituta na vila. Nem palavra havia na língua local para nomear tal criatura. Ana Deusqueira era sempre motivo de êxtase e suspiração. ${ }^{32}$

A simples convocação da "puta legítima"33 abala todas as formalidades da ocasião, reafirmando a sua presença como fenômeno instaurador da ruptura, da cesura com a ordem. Suas atitudes e seu discurso são assumidamente de confronto com os representantes do poder e ganham maior intensidade, a partir do momento em que é colocada em contraste com D. Ermelinda. Mulher como ela, ser também marginal dentro de uma sociedade de másculos poderes, porém, esposa subserviente de uma autoridade masculina.

${ }^{31}$ COUTO, 2000, p. 27.

32 COUTO, 2000, p. 30.

${ }_{33}$ COUTO, 2000, p. 31. 
Como mulher "sempre em pose" ${ }^{34}$, Ana Deusqueira é personagem ex-cêntrica, instauradora de um choque entre duas forças ideológicas: o poder, a ordem, em contraponto com a margem, o outro. É como autoridade, perita em assuntos pendentes, que a prostituta é convocada pelo administrador, a fim de solucionar o grande mistério de Tizangara : a explosão dos Boinas Azuis, soldados da ONU, trazidos a fim de auxiliar o processo de paz no pós-guerra. Aqui reside, mais uma das artimanhas do narrador para prender a atenção do leitor, pois o fantástico e o insólito da situação são pontuados pelo satírico de suas conseqüências. Não é o sumiço que mais aguça a curiosidade, mas o que sobra dele: um pênis decepado. Na cena desta irônica "missão de inquérito", não há lugar para os médicos legistas, pois a singularidade do acontecimento guarda certos vestígios desviantes, corroborados pelo veredito da competente meretriz: "- Essa coisa, como o senhor polícia chama, essa coisa não pertence a nenhum dos homens daqui." 35

A firmeza de Ana Deusqueira e a sua postura altiva e imponente redimensionam o ambiente inquiridor. É dela a palavra de reconhecimento, é dela a autoridade sob o "sexo maisculino" 36, é dela o gesto, o comando, o estalar de dedos que comanda o povo a empurrar a viatura. "Emoldurada, mão sobre as coxas" ${ }^{\prime 3}$, Ana Deusqueira impera absoluta como uma voz desviante dos modelos do poder.

As regras de conduta são cortadas, porque o próprio órgão analisado, por ela, instaura o caminho desviante tomado pelo narrador. O pênis decepado instaura o satírico, o dionisíaco poético no texto narrativo, porquanto representa a carnavalização do momento político. Se os préstimos da prostituta servem como forma de ironizar "a descentralização" e "a promoção da iniciativa local"38, o órgão masculino metaforiza a impotência do patriarcado, a ineficiência e a vulnerabilidade da ordem imposta. Por trás (e, não é este o ponto de vista do olhar narrativo ?) deste "sexo avultado e avulso", há toda uma ironia, uma sátira

\footnotetext{
${ }^{34}$ COUTO, 2000, p. 30.

35 COUTO, 2000, p. 32.

${ }^{36}$ COUTO, 2000, p. 34.

${ }^{37}$ COUTO, 2000, p. 34.

${ }^{38}$ COUTO, 2000, p. 29.
} 
aos podres poderes, que, na tentativa de centralização e monopólio, não conseguem se direcionar, antes perderam o rumo e, como o pênis decepado, preso à ventoinha fálica, apontam para todas as direções sem sequer definir-se por uma, desnorteados como estão na própria artimanha do discurso. Neste sentido, como são apropriadas as palavras de Alfredo Bosi, ao sublinhar que o humor, a ironia, o satírico, corta "toda ligação com as formas e os significados vigentes" ${ }^{\prime \prime}$.

Outro índicio do canto paródico, do "canto ao lado de", é o discurso do administrador, quando, ao escrever "quase por via oral" 40 , portanto, com a mesma proposta do narrador, deixa cair por terra as suas intenções, ocasionando, assim, o desmascaramento dos abusos do poder: "Agora a situação era muito contrária. Era preciso mostrar a população com a sua fome, com suas doenças contaminosas. (...) Para viver num país de pedintes, é preciso arregaçar as feridas, colocar à mostra os ossos salientes dos meninos." ${ }^{11}$

Desta forma, o relatório oficial é aqui empregado como forma de questionar a própria versão imposta dos fatos. O comércio da miséria e a riqueza sobre a desgraça alheia fazem do romance mais um canto paródico de Mia Couto, porquanto, o texto não hesita em mostrar, mesmo que irônica e sarcasticamente, "a crítica aos novos poderes, ao desvio de bens, à corrupção, ao desrespeito pelos valores morais e éticos" ${ }^{\text {”2 }}$, pondo em cheque, assim, a validade de certos discursos oficias e denunciando aquela "actual palavra de ordem: juntar os destroços, facilitar a visão do desastre" ${ }^{43}$.

O relatório de Estevão Jonas desvela a total falta de sintonia do homem político com a tradição de seu povo. Mais uma vez, sob a fina ironia do narrador, que nenhum detalhe deixa escapar, "o primeiro escrito do administrador" deixa registrado no papel um discurso verbalizado sob o signo desconcertante do mal hálito. Não resta dúvida, portanto, de que há uma incompatibilidade dos homens do poder com os heróis da tradição

\footnotetext{
${ }^{39}$ BOSI, 2000, p. 193.

${ }^{40}$ COUTO, 2000, p. 75.

${ }^{41}$ COUTO, 2000, p. 77.

${ }^{42}$ LEITE, 2000, p. 253.

${ }^{43}$ COUTO, 2000, p. 77.
} 
e com os sonhos. A utopia milenar e a esperança mítica de eras originais são violentamente substituídas pela distopia e pela arbitrariedade de um país manipulado por poucas, mas, desastrosas mãos, que contaminam e redimensionam a aura dos sonhos.

Sob as mãos que "abusam do Poder", cujos "dedos desatam-se a aquecer" ${ }^{44}$, pesa o fogo consumidor que arde e destrói a terra, "por causa e culpa dos governantes que não respeitam as tradições, não cerimoniam os antepassados" ${ }^{45}$. Dialogando ironicamente com o mito de Prometeu, as mãos geradoras de fogo aquecem apenas em favor próprio e não em ajuda aos outros homens, porquanto, segundo o discurso do administrador, representante legítimo do poder instituído, "trabalhar com as massas populares é difícil", trata-se de "uma grande maçada, essas maltas pobres" ${ }^{46}$. O risco da chama, entretanto, ultrapassa as massas populares, porque não descarta a possibilidade de reverter a sua direção. No alerta final, paira o medo das inevitáveis conseqüências: "O povo é a concha que nos abriga. Mas pode, repentemente, tornar-se o fogo que nos vai queimar" ${ }^{\prime 4}$.

Grande ironia a deste narrador que, sob o signo da imaginação fecundante, instala o satírico também através do vôo de um órgão infecundo e estéril, que vem pairar nos cômodos do Administrador no momento em que se encontra com uma mulher anônima. A posse do corpo desta mulher não se realiza, pois, no lugar do fogo do desejo, surge o órgão voador inutilizado, ironizando, assim, o papel masculino inconcluso e decepado.

Muito longe das visões apocalípticas, o clarão e a explosão contribuem para ridicularizar a coragem masculina. A Ilha de Patmos e a visão escatológica joanina dão lugar à vila de Tizangara e à contemplação estupefata de Estevão Jonas. Neste momento, sob o signo do vôo, o satírico plaina sob o texto e intensifica o escárnio à covardia do homem diante da esposa e o absurdo da situação flagrante:

(...) Pois o tal sexo voador, depois de rasar a minha pessoa, se foi pespregar na pá da ventoinha. E ficou rodopiando lá no tecto, como

\footnotetext{
${ }_{44}$ COUTO, 2000, p. 94.

${ }^{45}$ COUTO, 2000, p. 97.

${ }^{46}$ COUTO, 2000, p. 97.

${ }^{47}$ COUTO, 2000, p. 99.
} 
equilibrista nas alturas do circo.

Decidi aumentar velocidade na rotação da ventoinha. Pudesse ser que a coisa se despegasse, em fraqueza centrífuga. Acertei o botão nos máximos. Mas qual nada: o pendurico não despegava, suspenso na ilusão de estar vivo. Jogava à cobra-cega? (...)

Quando chegou a minha esposa eu tive que mentir. Não podia revelar com quem estava na altura do acontecimento. ${ }^{48}$

O "órgão de macho" ironiza o poder sem direção, que, preso à ventoinha, aponta para todos os lugares, sem ir a nenhum deles. Tal situação evoca aquela ironia assaltante, de que nos fala Linda Hutcheon. Como não perceber que, neste símbolo fálico voador, uma "invectiva corrosiva e um ataque destrutivo tornam-se as finalidades inferidas - e sentidas" ${ }^{49}$ ? A imagem do pênis fincado no ventilador acentua a crítica ao poder castrado e, no discurso narrativo, deflagra "uma amargura que pode sugerir não um desejo de corrigir, mas simplesmente uma necessidade de registrar desprezo e ironia" ${ }^{0}$. Aqui, o vôo da imaginação é o vôo satírico, cômico, que denuncia a proposta desviante do vôo poético de Mia Couto, afinal de contas, conforme ele próprio nos adverte: "quem imagina, é porque não se conforma com o real estado da realidade" 51 .

E porque imagina, porque não se conforma com o presente da realidade moçambicana, Mia Couto deixa transparecer na "Fala do feiticeiro Andorinho" (cap. 14) o outro lado do vôo. O humor satírico de Ana Deusqueira e a corrosiva imagem do órgão decepado dão lugar a uma amargura não menos irônica e intencionalmente desprezível em relação à situação pós-colonial no seu país. Da metáfora do vôo rasante do pênis somos levados ao espaço metonímico da vila. Tizangara local imaginário, mas pode ser também, um outro lugar, quem sabe, um reflexo da própria terra moçambicana: “(...) na vila, ninguém nos garante. Nem a terra, que é propriedade exclusiva dos deuses, nem a terra é poupada das ganâncias. Nada é nosso nos dias de agora. Chega um desses estrangeiros, nacional ou de fora, e nos arranca tudo de vez. Até o chão nos arrancam." ${ }^{52}$

\footnotetext{
${ }^{48}$ COUTO, 2000, p. 52.

${ }^{49}$ HUTCHEON, 2000, p. 85.

${ }^{50}$ HUTCHEON, 2000, p. 85.

${ }^{51}$ COUTO, 1998, p. 21.

${ }^{52}$ COUTO, 2000, p. 156.
} 
Interessante observar que, diferente do itálico, utilizado no relatório oficial do administrador, o grafo empregado na fala do feiticeiro é o tipo compacto, arquitetonicamente ereto, portanto, não inclinável, não tendencioso. Muito perspicaz o artifício deste narrador que se desvia do discurso em itálico, sob o signo do vôo de um órgão decepado, e aporta no terreno firme da escrita "por via oral" 53 de Andorinho, homem com nome de ave, de recado de vôo, que procura ensinar ao estrangeiro italiano a "deslumbrância da viagem" ${ }^{54}$ para um outro tempo. Não o atual, não o das sobrevivências, mas o de um futuro, tempo utópico possível graças ao sonho, ao vôo da imaginação, da invenção e da desconstrução e desestabilização do discurso do poder.

Se o recurso do "órgão de macho" voador apela para uma ironia ridicularizadora, acreditamos que a fala do feiticeiro ultrapassa o satírico, atinge a amargura e, por fim, aponta para uma possível mudança, para uma espera de outro nascer do sol:

Falam muito de colonialismo. Mas isso foi coisa que eu duvido que houvesse. O que fizeram esses brancos foi ocuparem-nos. Não foi só a terra: ocuparam-nos a nós, acamparam no meio das nossas cabeças. Somos madeira que apanhou chuva. Agora não acendemos nem damos sombra. Temos que secar à luz de um sol que ainda não há. Esse sol só pode nascer dentro de nós. Está-me seguindo, completo ?55

As vozes do poder são aqui reveladas por uma escrita romanesca poética inconformada e sintonizam com aquele "cômico nostálgico", de Alfredo Bosi, que "parodia não, evidentemente, o mito primordial, mas, ao contrário, é a cultura urbana, problemática, que já não mantém o sabor das origens; antes, 'perverte-se' com o discurso psicológico e crítico..." 56 . Contaminada pela ironia e pela paródia, o canto destece a trajetória do poder e, em seu lugar, faz surgir outra, a das vozes marginais que constituem uma espécie de coralidade no texto. Rompendo as barreiras cerceadoras, a escrita miacoutiana reúne faces de vários gêneros: o satírico, a ironia, a paródia e o canto dionisíaco constroem-se através da

\footnotetext{
53 COUTO, 2000, p. 75.

${ }^{54}$ COUTO, 1999a, p. 57.

${ }_{55}$ COUTO, 2000, p. 158.

${ }^{56}$ BOSI, 2000, p. 195.
} 
imaginação criadora do discurso poético escarnecedor, do epistolográfico, do documental e do ficcional. É, por fim, o próprio texto, enquanto estância literária, que faz coro com aquela barthesiana "língua fora do poder" $"$. Na trapaça salutar, na revolução do modelo imposto, o romance não só permite o questionamento de discursos estabelecidos, como também, ele próprio, desvia-se das formas estruturais e voa livremente entre os territórios dos gêneros literários. Duplo logro o deste escritor moçambicano, que, nas malhas do discurso barthesiano, trapaceia ironicamente o discurso do poder - como acontece na desconstrução imaginária dos relatórios oficiais do administrador - e faz o seu texto resplandecer como aquele de "grafo complexo das pegadas de uma prática: a prática de escrever". ${ }^{5}$

Se ao leitor é permitido pisar o chão do texto, é porque o seu autor o faz primeiro. E, ainda aqui, não é possível ver uma escrita sintonizada com a metáfora do vôo ? Não é possível acompanhar os passos alados de uma escrita sedutoramente descontrutora, satírica, irônica e paródica ? Ora, como não identificar a voz criadora de Mia Couto com a do poeta-narrador bosiano, que, ao instaurar um irônico e delicioso engano na fala do poder, "assume o destino dos oprimidos no registro de sua voz" precariedade da sorte política, social e cultural do homem moçambicano ? Afinal, são as vozes, outrora sufocadas, que ganham espaço no texto e o constroem sob a forma de um coro. Segundo Bosi, este "atua, necessariamente, um modo de existência plural. (...) Mas o coro não se limita a evocar uma consciência de comunidade; ele pode também provocá-la, criando vozes que compõem o sentimento de um destino comum" ${ }^{60}$. No romance, deparamo-nos, portanto, com um coro expectante e propiciador de uma outra face do discurso de Mia Couto: o mito-poético, o lírico.

\footnotetext{
57 BARTHES, 1989, p. 16.

${ }^{58}$ BARTHES, 1989, p. 17.

${ }^{59}$ BOSI, 2000, p. 213.

${ }^{60}$ BOSI, 2000, p. 215.
} 


\section{4 - Os caminhos da resistência : o vôo e o sonho}

Na trilha do pensamento de Alfredo Bosi, outro caminho do poético manifesta, enquanto resistência ao poder: o da fala mitopoética que "deplora as úlceras que o dinheiro fez e faz na paisagem e tenta reviver a grandeza heróica e sagrada dos tempos originários, unindo lenda e poema, mithos e epos" ${ }^{\prime \prime}$.

Perscrutar os meandros de O Último Vôo do Flamingo significa embarcar numa viagem, onde o vôo e o sonho se fazem metáforas imprescindíveis para seguir os passos no terreno arenoso do texto, onde as armadilhas, ao contrário dos explosivos, aguçam o prazer do leitor, seduzem-no e apontam os caminhos da resistência numa narrativa romanesca salutarmente minada pelo lírico. Planar pelo espaço textual de Mia Couto é usufruir aquela sensação de caminhar com o calcanhar, "O pé e o ante-pé, passo sem pegada", é passar pelo "terreno minado como Jesus se deslocou sobre as águas" ${ }^{2}$.

É bom lembrar que, no discurso do escritor moçambicano, a fala mitopoética não se constitui num regresso passadista, numa recuperação escapista de épocas heróicas passadas, até porque, estas já não existem mais, sufocadas que foram pela ótica do colonizador (e também dos próprios revolucionários que assumiram o poder após a Independência). Logo, o passado recuperado não é o da colonização imposta, mas é o passado enquanto tempo da liberdade, da inocência, da pureza, do imaculado. Neste sentido, a proposta miacoutiana muito se aproxima da de Alfredo Bosi, pois, "a resposta ao ingrato presente é, na poesia mítica, a ressacralização da memória mais profunda da comunidade"63. Assim, no coro poético da resistência, o narrador abre espaço para o canto de Temporina, de Ermelinda e de seus pais, Sulplício e a Mãe inominada.

Personagem com recado no nome, Temporina é apresentada como a mulher escamosa, a que vive no espaço entre, a que "só anda no corredor $^{364}$. Possuidora de dois tempos, um rosto envelhecido e outro no

\footnotetext{
${ }^{61}$ BOSI, 2000, p. 173.

${ }^{62}$ COUTO, 2000, p. 204.

${ }^{63}$ BOSI, 2000, p. 173.

${ }^{64}$ COUTO, 2000, p. 41.
} 
"corpo surpreendentemente jovem e sedutor, Temporina configura-se como personagem sob a aura mítica do tempo que não possui início nem fim. Diante do outro, do estrangeiro, a sua reação é não a de estranhamento, mas de aproximação, de paixão. É ela, que ao ensinar Massimo Risi a caminhar, lança-lhe o encanto da paixão, num verdadeiro pas de deux, instaurando assim uma pedagogia do caminhar pelas trilhas do amor: "Parecia que dançavam, o italiano aliviando o seu peso à medida que o seu pé se afeiçoava ao chão. Temporina o ia encorajando: pise como quem ama, pise como se fosse sobre um peito de mulher. E o conduzia, de encosto e gesto." 15

Parodiando o mito de Perseu, que "se sustenta sobre o que há de mais leve, as nuvens e o vento" ${ }^{\prime \prime}$, Massimo Risi baila, conduzido pelas mãos da mulher, "aliviando o seu peso". Não estaríamos, aqui, diante de uma imagem circular, dançante, cíclica, que recupera a imagem mítica do tempo que não se esgota, do tempo contínuo? Ora, não seria por acaso que "em flagrante de amor Temporina rejuvenescia", sem qualquer "cicatriz do tempo" ${ }^{67}$ e anunciaria a gestação do filho de Risi ("Esta noite fiquei grávida consigo" ${ }^{68}$ ). Ao contrário do esperado, a gravidez é processada a dois, não é apenas ela, mas ambos os gestantes. Ela, do filho. Ele, de uma nova perspectiva de olhar o outro. Esta é tão forte a ponto dos papéis e das fotos serem insuficientes de registrar e capturar as falas e as imagens de Tizangara. Aprisioná-las já não era mais possível, porque o tempo inscrito era já o da liberdade do vôo, o das revelações de mistérios, o de "soltar a palavra"

Esta liberdade confere ao romance um dos aspectos da proposta calviniana de leveza. Os passos fluidos de Temporina, as palavras livres de Massimo Risi e a dança pedagógica de pisar a terra como quem possui o corpo da mulher são algumas das imagens da leveza que assumem um valor emblemático na narrativa. Elas constituem aquelas "invenções literárias que se impõem à memória mais pela sugestão verbal que pelas

\footnotetext{
${ }^{65}$ COUTO, 2000, p. 70.

${ }^{66}$ CALVINO, 1990, p. 16.

${ }^{67}$ COUTO, 2000, p. 70.

${ }^{68}$ COUTO, 2000, p. 60.

${ }^{69}$ COUTO, 2000, p. 152.
} 
palavras"70. Daí, a sugestão da gravidez e do caminhar a dois, daí a impossibilidade de registrar o que está para além das palavras. É a própria narrativa que se deixa enfeitiçar pelo vaticínio de Andorinho: "Só tenho fala para o que invento" 71 .

Inventar é, aqui, a palavra de ordem. Com a personagem Temporina, a imaginação inventiva do narrador-poeta funda no texto ficcional o seu repertório potencial "do hipotético, de tudo quanto não é, nem foi e talvez não seja, mas que poderia ter sido"72. Espaço e tempo parecem se diluir diante desta personagem. A sua casa "era um lugar de espíritos"73, de "acesso a outras visões"74. O seu corpo era "todo o redesenhar do tempo" 75 .

Desta forma, o mítopoético invade o texto e este se deixa inscrever no convívio salutar da realidade e da fantasia, reiterando aquela "esperança de um tempo outro, principial, em que o trágico da guerra e da miséria se transfigura na ordem cósmica dos acontecimentos elementais, organizados por uma outra lógica" "76, a da criação poética, mítica e lírica.

Se Temporina é nome para além do tempo, Ermelinda - a mulher que, a princípio, se opõe a Ana Deusqueira - é nome em forma de gerúndio, é presente em processo, é percurso de mudança. Num primeiro momento, sua postura é subserviente ao código da ordem masculina instituída. Em outro, assume a sua identidade fora do centro. Ela é Ermelinda, é o ermo, é a parte deserta, é a parte solitária, porque é mulher, é marginal, é socialmente morta. Ela reconhece a irmandade da marginalidade, na mesma medida em que o narrador reconhece e, como uma espécie de sacerdote-poeta, celebra o texto como um altar marginal e marca nele o descompasso entre o discurso do poder e os ritos originais. São mulheres que se unem - a prostituta de todos os homens e a esposa

${ }^{70}$ CALVINO, 1990, p. 30.

${ }^{71}$ COUTO, 2000, p. 158.

${ }^{72}$ CALVINO, 1990, p. 106.

${ }^{73}$ COUTO, 2000, p. 65.

${ }^{74}$ COUTO, 2000, p. 66.

75 COUTO, 2000, p. 64.

${ }^{76}$ LEITE, 1998, p. 51. 
de um só - e a elas cabe, agora, a instauração de uma nova ordem: a união deliberada de seres, outrora, marginais. Ermelinda, assim, corrobora o discurso mitopoético na narrativa, na medida em que o seu tempo se faz em um presente mutável, da subserviência à resistência. A sua voz não é mais a que simplesmente obedece ou retruca, mas é a que comanda, a que impera diante do silêncio dos homens:

A prostituta encolheu o pescoço para se render à carícia da outra e as duas choraram. Os homens, nós, escutávamos em silêncio. Elas eram donas, exclusivas, do que ali se passava. Ana se ergueu amparada por Ermelinda. Enquanto se internavam na sala se escutou a voz da Ermelinda:

- Você saia desta casa Estevão.

- Sair da minha casa!? Para ir para onde?

- Vá ter com Jonassane. Eu nunca mais quero ver-lhe.

$\mathrm{E}$ as duas mulheres saíram. ${ }^{77}$

Através da união das mulheres-irmãs opera-se uma metamorfose na ordem masculina. Agora, não mais os órgãos são decepados, mas o homem de corpo inteiro é despojado de seu poder e do espaço que domina: a casa. Esta, agora, não mais the pertence. O seu discurso se desmantela diante da voz imperativa da mulher. São elas as vozes anoitecidas que amanhecem nas páginas do céu romanesco. O romance torna-se, assim, a casa textual entretecida pela miticidade das vozes marginais destas mulheres. E as vozes da Mãe do tradutor e de seu pai, Sulplício, reiteram-no como espaço de manifestação do discurso mitopoético do narrador.

Sulplício e a Mãe impregnam a narrativa de tonalidade mítica, na medida em que trazem a metáfora do vôo e do sonho, representada pela imagem do flamingo. Ana Mafalda Leite atenta para o fato de que "a estória do flamingo, que dá título ao romance, é o mito organizador da narrativa e veicula uma sabedoria, dando-se a ler com diferentes sentidos" ${ }^{\text {" }}$.

Nos ensinamentos da Mãe, o flamingo é contemplado como símbolo do sagrado, da própria tradição milenar, resgatada pelas recordações do tradutor: "Em fins de tarde, os flamingos cruzavam o céu.

77 COUTO, 2000, p. 199.

${ }^{78}$ LEITE, 2000, p. 254. 
Minha mãe ficava calada, contemplando o vôo. Enquanto não se extinguissem os longos pássaros ela não pronunciava palavra. Nem eu me podia mexer. Tudo, nesse momento, era sagrado." 79

Interessante observar que o momento sagrado, o da aparição do flamingo, requer todo um ritual, que o tradutor, com os olhos ingênuos de criança, ainda não consegue captar. O silêncio acompanha toda a trajetória do flamingo, instaura a magia e o sagrado do vôo e prenuncia o canto da Mãe: “- Este canto é para eles voltarem, amanhã outra vez!" ${ }^{80}$ Sua voz recupera um tempo original e invoca um futuro por vir, num ciclo contínuo de uma espera mítica, por excelência. Com ela, há a pedagogia do sonho, do vôo mágico para um lugar "longe, mas não distante" ${ }^{11}$ e a iniciação do filho nos "sagrados xicuembos" 82 . Como a criança, de "Nas águas do tempo", que consegue ver com o avô a outra margem, a garça atravessando o céu, e cujos olhos "se neblinaram até que se poentaram as visões"83, o jovem falador da estória aprende, com o vôo do flamingo e da Mãe, a carregar "as asas como duas saudades", a "dormir como um deserto", a "esquecer que sabia voar", a "ignorar a arte de pousar sobre a terra" e, por fim, a "repousar" 84 . Depois de perceber a arte de voar e a engenharia de ser ave, seus olhos vêem o flamingo, para além da estória contada. É a fantasia que invade a realidade do narrador e o conduz ao reino do sonho. Estabelece-se, assim, uma espécie de pacto: Mãe e filho deveriam se encontrar "no momento em que ela estivesse despedindo de viver" ${ }^{85}$. É voz que fala, que (com)pactua, que canta, e porque canta, deixa ressoar uma entoação mítica constante, mas é também voz que silencia no princípio e no fim do ritual de iniciação: "No escurecer, a voz de minha mãe se desvaneceu. Olhei o poente e vi as aves carregando o sol, empurrando o dia para outros aléns. Aquela era minha última noite desse

\footnotetext{
${ }^{79}$ COUTO, 2000, p. 49.

${ }^{80}$ COUTO, 2000, p. 50.

${ }^{81}$ COUTO, 2000, p. 118.

${ }^{82}$ COUTO, 2000, p. 50.

83 COUTO, 1994, p. 17.

${ }^{84}$ COUTO, 2000, p. 118.

${ }^{85}$ COUTO, 2000, p. 50.
} 
retiro nos matos. Manhã seguinte eu já entrava na vila, como quem regressa a seu próprio corpo depois do sono." $\$ 6$

$\mathrm{Na}$ experiência da aprendizagem, o vôo ganha outras dimensões. O flamingo, que cruza o céu, encerra um dia, mas desperta a esperança de um outro raiar do sol. O pacto une mãe e filho, mas não isenta um desfecho inexorável. A morte pode até separá-los, mas não encerra a possibilidade do sonho, pois, nas asas do flamingo, o tradutor contempla, em silêncio, o último vôo da mãe para o "sítio onde não há nenhum lugar" 87 .

Reunindo o ar, implícito na metáfora do vôo, e a água, na corrente fluida das palavras e do canto da mãe, o narrador-tradutor reencontra sua condição na terra que habita e no fogo da guerra, que consome e se amadurece "no ódio da gente miúda" 88 , e da palavra, que inventa falas com "o sotaque de nuvem" 89 . Fincado nesta, com raízes profundamente mitopoéticas, é que ele se apresenta não apenas como escritor ou transcritor, mas como "falador da estória", num discurso alquimicamente lírico: "Só isto: sou árvore nascida em margem. Mais lá, no adiante, sou canoa, a fugir pela corrente; mais próximo sou madeira incapaz de escapar do fogo" 90 . Confirma-se, assim, a proposta de Ana Mafalda Leite, ao dizer que "as imagens desta fauna com asas, repõem o vôo da imaginação mítica, refazendo uma cosmologia própria, um conjunto de crenças e de conhecimentos, um saber compósito, que abrange o universo natural e humano" $"$.

Muito próximo da perspectiva do poeta-narrador de Alfredo Bosi, com o trabalho da memória inventiva, o narrador recupera a origem, a infância, o espaço mítico onde "o tempo não tinha inventado a noite" É na rota do vôo do flamingo que o vôo poético se realiza, pois a visão miacoutiana permite lançar asas ao passado, ao tempo do princípio,

\footnotetext{
${ }^{86}$ COUTO, 2000, p. 119.

${ }^{87}$ COUTO, 2000, p. 117.

${ }^{88}$ COUTO, 2000, p. 116.

${ }^{89}$ COUTO, 2000, p. 47.

${ }^{90}$ COUTO, 2000, p. 50.

${ }^{91}$ LEITE, 1998, p. 48.

${ }^{92}$ COUTO, 2000, p. 117.
} 
estabelecendo no texto as metáforas do voar e do sonhar. É na ciência de ser ave e na engenharia de voar que parece buscar as raízes do contar e do falar e, com elas, a poeticidade do escrever. Logo, não há como duvidar que a mão do prosador é a mesma do poeta, em Raiz de Orvalho, porquanto é a recuperação mitopoética da infância como pátria, como lugar primordial, que atravessa os riscos das escritas.

Duas são as saudades, como as asas do flamingo, diz a mãe ao filho. E a memória narrativa, seguindo a trajetória aérea da ave, parece funcionar sob uma dualidade lírica: de um lado, a recordação da Mãe, cujos conselhos e falas eram marcados pelo silêncio, de outro, a voz do pai, Sulplício, que suplica e suplicia pela consciência do filho. Ao pai, que perdera a força e a crença, resta a esperança na imagem do filho. Se aquele fala "pela voz dos outros" morte ocupara, essas vezes, meu corpo, mas nunca me chegara a levar. Nos saberes locais, aquela resistência era um sinal: eu traduzia palavras dos falecidos. Essa era a tradução que eu vinha fazendo desde que nascera. Tradutor era, assim, meu serviço congênito" ${ }^{4}$.

Mais do que traduzir, mais do que transcrever a fala do pai do gravador, o ofício do filho é congênito e necessário, porque a sua voz é a ligação entre a realidade caótica e incompreensível das explosões do pós-guerra e a fantasia de um mundo onírico, mítico, original. Segundo Ana Mafalda Leite, o tradutor cumpre a função burocrática de permitir a comunicação entre estrangeiros e nativos, mas também faz a ponte entre mundos diferenciados - o do pai e, conseqüentemente, dos mais velhos da aldeia, dos detentores de um saber feito de experiências, com o dos outros homens - e tempos distanciados - o "de antes e de agora, entre o onirismo dos mortos e a derrota dos vivos, entre a terra abolida e um céu numinoso e derradeiro, como o é o primeiro-último poente do vôo do flamingo" 95 .

Neste momento, parece ressoar novamente, no romance, aquela leveza, de que nos fala Ítalo Calvino, tão característica das obras literárias do fim de milênio, porquanto as metáforas do vôo e do sonho permitem a invenção daquelas visões polimorfas da tradição moçambicana. O real

\footnotetext{
${ }^{93}$ COUTO, 2000, p. 144.

${ }^{94}$ COUTO, 2000, p. 143.

${ }^{95}$ LEITE, 2000, p. 254.
} 
e a fantasia interagem em total liberdade, sem linhas fronteiriças. Na rota deste mundo imaginário, o romance reverte o caminho da criação, quando, ao final, numa grande cena apocalíptica, faz a vila de Tizangara e todas as coisas desaparecerem misteriosamente, como numa espécie de efeito máximo das bombas. Tudo passa do Cosmos ao Caos: as fotos, os relatórios, os habitantes, a vila. Em terra, "não havia nada senão um imenso abismo" 96 , consequência desgastante e inevitável de uma terra entregue a "ambiciosos que governaram como hienas, pensando apenas em engordar rápido" 97 . É este "roubo da alma", este "desamor pela terra e pelos valores coletivos" 98 , pontuado por Ana Mafalda Leite, que une a face crítica à face mitopoética do escritor, mas, nem por isso totalmente descrente. E, inusitadamente, a esperança parece ressurgir em meio ao nada, apontando o prenúncio de um outro tempo: "Já no longe, me pareceu ser não um barco, mas um pássaro. Um flamingo que se afastava, pelos aléns. Até tudo ser neblina, tudo nuveado." 99

Ora, se em toda a narrativa, a presença da ave é evocada, o final não poderia ser diferente, pois é já no limiar das forças e das expectativas que ela reaparece para confirmar a possibilidade de se instaurar uma nova realidade. É sob o signo da espera que a voz do pai vaticina o vôo do flamingo; é sob a imagem de um "pássaro de papel" que o discurso oficial dos relatórios cai abismo abaixo; por fim, é sob as metáforas do vôo e do sonho que se abrem os caminhos da resistência e da esperança: "Aceitei a sua palavra como de um mais velho. Face à neblina, nessa espera, me perguntei se a viagem em que tinha embarcado meu pai não seria o último vôo do flamingo. Ainda assim, me deixei quieto, sentado. Na espera de um outro tempo." ${ }^{\prime 00}$

No tempo por vir, no tempo do último vôo do flamingo, o tradutor cessa as verbalizações e aquieta-se, realizando definitivamente o aprendizado do silêncio. Somente com este, é possível recuperar o "nãotempo", a sua "mineral essência" 101 , aceitar as palavras do pai e ouvir a

\footnotetext{
96 COUTO, 2000, p. 219.

97 COUTO, 2000, p. 220.

${ }^{98}$ LEITE, 2000, p. 255.

99 COUTO, 2000, p. 223.

${ }^{100}$ COUTO, 2000, p. 224-225.

${ }^{101}$ COUTO, 2000, p. 136.
} 
canção da mãe, porque é neles que se encontram os momentos os raios de um novo sol por surgir.

O mundo parece acabar e, obedecendo aos conselhos do pai, o tradutor urge reencontrar o caminho de volta, a casa primeva. Na pátria da infância, do tempo imaculado, do espaço inicial, busca o reiniciar de uma outra história. No sonho, na esperança, o vôo reaparece como força impulsionadora de uma transformação: no Caos espera-se o nascer de um novo sol, de um novo Cosmo. O tempo, em O último vôo do flamingo, é o tempo do sonho e do vôo, posto que, no romance, as imagens da ave pernalta, do canto da Mãe, do abismo, da canoa e do pai desossado são algumas das recriações fundadoras, que apontam para uma nova terra, não mais sonâmbula ou anoitecida, mas acordada, amanhecida, na espera do último vôo do flamingo.

Desta maneira, utilizando as metáforas do vôo e do sonho, a prosa miacoutiana se revela profundamente contaminada por um discurso poético que opta ora pela face satírica - investindo na ironia e na paródia -, ora pela face lírica, mitopoética - trazendo à tona a experiência subjetiva do sujeito com a sua realidade. Planando livremente por outras vozes e por sua própria, Mia Couto se mostra pleno conhecedor dos múltiplos terrenos literários e proporciona aos aventureiros de seu texto a mesma sensação de vôo e de sonho que paira na ambiência ficcional. Entre o satírico e o lírico, convida seus leitores ao vôo poético, por uma viagem onde o humor e a comicidade sublinham uma crítica requintada ao discurso do poder e o mitopoético e o lírico despertam as imagens e as recordações de um tempo primordial e original.

\section{Referências Bibliográficas}

ANDRADE, Carlos Drummond de. Poesia e Prosa:Rio de Janeiro: Nova Aguilar, 1983.

BARTHES, Roland. Aula. São Paulo: Cultrix, 1989.

BOSI, Alfredo. O Ser o Tempo da Poesia. 6. ed. São Paulo: Companhia das Letras, 2000.

COUTO, Mia. Cronicando. 2. ed. Lisboa: Caminho, 1998.

COUTO, Mia. Escrevoar. In: WHITE, Eduardo. Poemas da ciência de voare da engenharia de ser ave. Lisboa: Caminho, 1992, p. 9-10. 
COUTO, Mia. Estórias Abesonhadas. Lisboa: Caminho, 1994.

COUTO, Mia. Infância, minha pátria. Colóquio/Letras. Lisboa, Fundação Calouste Gulbenkian, n. 84, p. 59, março de 1985.

COUTO, Mia. O último vôo do flamingo. Lisboa: Caminho, 2000.

COUTO, Mia. Raiz de orvalho e outros poemas. 2. ed. Lisboa: Caminho, 1999a.

COUTO, Mia. Terra Sonâmbula. Rio de Janeiro: Nova Fronteira, 1995.

COUTO, Mia. Vozes Anoitecidas. 5. ed. Lisboa: Caminho, 1999b.

HUTCHEON, Linda. Poética do Pós-Modernismo. Rio de Janeiro: Imago, 1991.

HUTCHEON, Linda. Teoria e política da ironia. Belo Horizonte: Editora da UFMG, 2000.

LEITE, Ana Mafalda. Oralidades e escritas nas literaturas africanas. Lisboa: Colibri, 1998.

LEITE, Ana Mafalda. Recensão: O último vôo do flamingo. Metamorfoses. Lisboa / Rio de Janeiro: Cosmos / Cátedra Jorge de Sena, n. 1, p. 253-255, 2000.

MELO NETO, João Cabral de. A educação pela pedra e depois. Rio de Janeiro: Nova Fronteira, 1997.

SAÚTE, Nélson. Os habitantes da memória: entrevistas com escritores moçambicanos. Praia; Mindelo: Embaixada de Portugal; Centro Cultural Português, 1998.

SECCO, Carmen Lúcia Tindó Ribeiro. Mia Couto e a incurável doença de sonhar. In: SEPÚlVEDA, Maria do Carmo; SALGADO, Maria Teresa (Org). África e Brasil: letras em laços. Rio de Janeiro: Atlântica, 2000, p. 261-286.

SECCO, Carmen Lúcia Tindó Ribeiro. O ar, as águas e os sonhos no universo poético de Mia Couto. Revista Gragoatá. Niterói: EDUFF, n. 5, p. 159-169, 1998.

STALLONI, Yves. Os gêneros literários. Rio de Janeiro: DIFEL, 2001.

TADIÉ, Jean - Yves. Le récit poétique. Paris: Presses Universitaires de France, 1978.

WHITE, Eduardo. Poemas da ciência de voar e da engenharia de ser ave. Lisboa: Caminho, 1992. 


\section{Resumo}

A leitura de O último vôo do flamingo, de Mia Couto, visa principalmente destacar a presença de dois caminhos: o satírico e o lírico. A apropriação de alguns procedimentos poéticos na construção da prosa romanesca permite a constatação dos recursos paródico e lírico, colocando-a sob o signo de Orfeu. A partir disso, observamos os jogos e os caminhos textuais da resistência em diálogo com as metáforas do vôo e do sonho.

\section{Abstract}

The reading of O último vôo do flamingo, by Mia Couto, reaches the presence of two main points: the satirical and the liric one. The appropriation of some poetic procedures in the fiction construction permits the verification of the parodical and the liric resources, putting it on the sign of Orpheo. From that perspective, we observe the textual ways of resistance in dialogue with the metaphores of the flight and the dream. 